\title{
Alchizan
}

ISSN 1907-0985, E ISSN 2442-8256

Vol. 16, No. 2, 2020, h. 201-224

DOI: https://doi.org/10.30603/am.v16i2.1875

\section{Kompetensi Peradilan Agama Menangani Perkara Cerai Gugat Dalam Tinjauan Fikih Islam}

\section{A. Zamakhsyari Baharuddin, Rifqi Qowiyul Iman}

STAIN Majene, Pengadilan Agama Manna

Email: ansamad90@gmail.com; rifqi1914@gmail.com

\begin{abstract}
This study aims to highlight the review of Islamic jurisprudence regarding the competence of religious courts in handling judicial divorce as a reflection of the view that judges' actions to terminate the marriage relationship are unjustifiable and the only divorce institution is divorce which is the husband's prerogative. The method applied is the descriptive-analytic research method with the main data source is library research. The results of this study indicate that the Religious Court is not only a state institution, but also a religious institution as recorded in the Islamic literature, and a judge with the authority to pronounce divorce is playing the role of amar makruf nahi mungkar, therefore his authority is not only legally valid in the state law, but also has its legitimacy regulated in Islamic jurisprudence.
\end{abstract}

Keywords: Divorce, Judicial Divorce, Religious Court

\section{The Competence of Religious Courts in Handling Judicial Divorce in Islamic Jurisprudence}

\begin{abstract}
Abstrak: Penelitian ini bertujuan untuk menyoroti posisi yurisprudensi Islam tentang kompetensi peradilan agama dalam menangani perkara cerai gugat sebagai bentuk refleksi terhadap pandangan yang menilai tindakan hakim memutus tali pernikahan tidak dapat dibenarkan dan lembaga perceraian satu-satunya adalah talāq yang tidak lain merupakan hak prerogratif suami. Metode yang diterapkan adalah metode penelitian deskriptif-analitik dengan sumber data utama bersifat penelitian kepustakaan. Hasil penelitian ini menunjukkan Peradilan Agama tidak hanya berkedudukan sebagai lembaga negara, namun ia juga merupakan lembaga keagamaan sebagaimana tercatat pada literatur-literatur dalam khazanah keislaman, dan seorang hakim yang dengan kewenangannya menjatuhkan talāq, sesungguhnya sedang menjalankan peran amar makruf nahi mungkar. Karenanya, setiap kewenangan yang dimilikinya selain memiliki pondasi yang dikuatkan oleh hukum negara juga dikokohkan dengan dasar hukum agama.
\end{abstract}

Keywords: Talāq, Kewenangan Peradilan, Peradilan Agama 


\section{A. Pendahuluan}

Pernikahan adalah suatu bentuk ajaran dari Allah swt. yang menjadi salah satu cara bagi makhluk-Nya untuk melestarikan kehidupannya dan menjadikan makhlukNya dapat menikmati hidup yang tenang dan halal. Manusia sebagai makhluk Allah swt. yang dianugerahi akal, iman, Islam dan nafsu syahwat hendaknya digunakan sesuai proporsi dari masing-masing. Misalnya nafsu syahawat pada diri manusia diberikan agar dapat menghasilkan keturunan, sedangkan anugerah iman, agama dan akal, menjadi sebuah berkewajiban bagi manusia dalam menghasilkan keturunan melalui ikatan pernikahan sebagaimana tuntunan dari Allah swt. melalui ajaran agama Islam. ${ }^{1}$

Ikatan pernikahan sebagai salah satu pemenuhan terhadap perintah Allah swt. dengan tujuan membentuk dan membina hubungan ikatan lahir batin antara seorang laki-laki dan seorang perempuan sebagai suami istri yang berlandaskan syariat Islam melalui ikatan perjanjian suci, namun di dalam perjalanan hubungan tersebut didapati adanya ketidakcocokan dan ketidakharmonisan yang menyebabkan terjadinya perceraian atau pemutusan hubungan pernikahan. Hal ini dikarenakan adanya pengabaikan hak dan kewajiban dari masing-masing pasangan, misalnya rentang adanya ketidakadilan jender.

Perbedaan jender (gender difference) melahirkan berbagai bentuk ketidakadilan, baik pada laki-laki maupun pada perempuan dalam hubungan pernikahan. Ketidakadilan jender ini termanifestasi dalam berbagai bentuk ketidakadilan, misalnya: marginilasasi, proses pemiskinan ekonomi, subordinasi, streotyping dan diskriminasi, pelabelan negatif, dan tindak kekerasan (violence). Persoalan-persoalan ini dapat terjadi pada ruang publik dan ruang domestik, khususnya dalam lingkungan rumah tangga seseorang, sehingga akhirnya berujung pada pemutusan pernikahan. ${ }^{2}$

Talāq sebagai salah satu lembaga pemutus hubungan pernikahan, sejatinya adalah hak perogratif suami. Namun dikarenakan ketiadaan i’tikad baik, suami

\footnotetext{
${ }^{1}$ Hamid Pongoliu, "Family of Sakinah, Mawaddah, Warahmah in the Concept of Islamic Marriage," Al-Mizan, Vol. 13, No. 1 (2017); 3.

${ }^{2}$ Rizal Darwis, "Hak Nafkah Batin Istri dalam Perkawinan: Telaah Fikih dan Hukum Nasional Perspektif Jender," Disertasi (Makassar: UIN Alauddin Makassar, 2016), 11.
} 


\section{A. Zamakhsyari Baharuddin, Rifqi Qowiyul Iman}

seringkali abai dengan kehendak istri yang ingin berpisah, karena baginya hubungan keduanya tidak lagi harmonis dan sulit diperbaiki. Hal demikian bisa saja terjadi dengan alasan untuk mengikat sang istri karena kecintaannya atau niat buruknya yang tidak diketahui. Padahal terkait hal tersebut Allah swt. telah menyatakan:

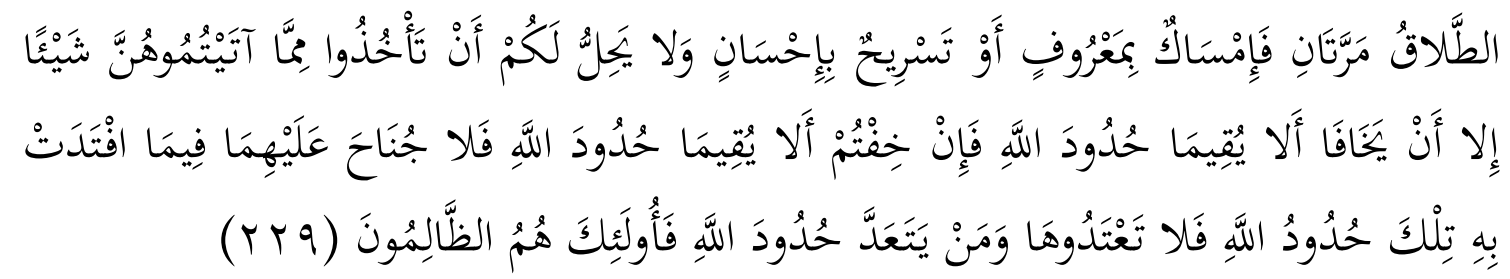

Terjemahnya:

Talak (yang dapat dirujuk) itu dua kali. (Setelah itu suami dapat) menahan dengan baik, atau melepaskan dengan baik. Tidak halal bagi kamu mengambil kembali sesuatu yang telah kamu berikan kepada mereka, kecuali keduanya (suami dan istri) khawatir bahwa keduanya (suami istri) khawatir tidak mampu menjalankan hukum-hukum Allah, maka keduanya tidak berdosa atas bayaran yang (harus) diberikan (oleh istri) untuk menebus dirinya. Itulah hukum-hukum Allah, maka janganlah kamu melanggarnya. Barangsiapa melanggar hukumhukum Allah, mereka itulah orang-orang zalim (QS al-Baqarah/2: 229). ${ }^{3}$

Allah swt. secara normatif telah menetapkan kewajiban guna melaksanakan ketetapan syariah kepada pribadi tiap-tiap muslim. Kewajiban-kewajiban syara tersebut lantas dilaksanakan berdasarkan pilihannya (ikhtiyār) sendiri tanpa ada intervensi ataupun paksaan dari pihak manapun. Namun pada kenyataannya, ketetapan-ketetapan tersebut seringkali dilalaikan dan oleh karenanya kewajiban menjaga pelaksanaan syariat diserahkan kepada hakim. Hal tersebut karena hakim berkewajiban untuk memutuskan hukum berdasarkan syariat serta mengukuhkannya dengan otoritas (sultah) yang diberikan kepadanya, dan dalam hal ini hakim melaksanakan perannya dalam kerangka al-amr bi al-ma'rüf wa al-nahy 'an al-munkar.

Cerai gugat dengan putusan talāq bāin șgrah yang diterapkan di lingkungan Peradilan Agama di Indonesia pada dasarnya merupakan salah satu bentuk keadilan yang telah lama diterapkan, utamanya dalam rangka memberikan perlindungan bagi hak perempuan yang ingin bercerai dari suaminya. Pasal 73 ayat (1) Undang-Undang

\footnotetext{
${ }^{3}$ Kementerian Agama RI, Ummul Mukminin: Al-Qur'an dan Terjemahan untuk Wanita (Ciputat: Penerbit Wali, 2010), 36.
} 
Nomor 7 Tahun 1989 sebagaimana telah diubah terakhir dengan Undang-Undang Nomor 3 Tahun 2006 dan perubahan kedua dengan Undang-Undang Nomor 50 Tahun 2009 (selanjutnya disebut UUPA) telah menggariskan bahwa dalam perkara cerai gugat, yang bertindak sebagai penggugat adalah istri. Di satu sisi, suami ditempatkan sebagai pihak tergugat, sehingga, baik suami maupun istri telah mempunyai jalur masing-masing dalam kaitannya dengan upaya menuntut perceraian. Dalam hal ini suami menempuh upaya cerai talāq, sedangkan istri menempuh upaya cerai gugat yang pada akhirnya hakimlah yang akan menjatuhkan țalāq.

Namun nyatanya, masih ada saja pihak yang menaruh shak (prasangka tidak benar) akan kewenangan Peradilan Agama Tersebut. Dikatakan bahwa dalam perkara cerai gugat, hakim tidak berwenang menjatuhkan taläq karena ia semata-mata merupakan hak prerogratif suami atas istrinya. Oleh karenanya, tindakan hakim memutus tali pernikahan tidak dapat dibenarkan dan lembaga perceraian satu-satunya adalah talāq yang tidak lain merupakan wewenang milik suami.

Berdasarkan realita tersebut bahwasanya perlu mengkaji tentang praktik cerai gugat dalam perspektif fikih. Hal demikian penting dilakukan dalam rangka memperkokoh kedudukan hakim serta menanamkan paham bahwa putusan-putusannya ataupun kewenangan terutama dalam perkara cerai gugat memiliki legitimasi dalam shara'dan undang-undang. Meskipun penelitian ini bertujuan untuk menyoroti posisi yurisprudensi Islam tentang kompetensi Peradilan Agama dalam menangani perkara cerai gugat, namun juga perlu menampilkan selayang pandang yang menunjukkan gambaran umum terkait ketentuan dan peraturan perundang-undangan Indonesia yang berlaku dalam konteks kekinian.

\section{B. Kompetensi Peradilan Agama dalam Penanganan Perkara}

Kata kompetensi berasal dari bahasa Belanda competentie, yang kadangkadang diterjemahkan juga dengan "kewenangan", sehingga kedua kata tersebut dianggap semakna. ${ }^{4}$ 2006), 25

${ }^{4}$ A. Rasyid Roihan, Hukum Acara Peradilan Agama, Ed. 2 (Jakarta: Raja Grafindo Persada, 


\section{A. Zamakhsyari Baharuddin, Rifqi Qowiyul Iman}

Lembaga-lembaga Peradilan di Indonesia sebagai bagian dari kekuasaan kehakiman dalam menjalankan tugas dan fungsinya tidak terlepas dari aturan perundang-undangan yang berlaku. Hal ini sebagaimana disebutkan dalam UndangUndang Nomor 48 Tahun 2009 tentang Kekuasaan Kehakiman, Pasal 18 bahwa kekuasaan kehakiman dilakukan oleh Mahkamah Agung dan badan peradilan yang berada di bawahnya, serta oleh sebuah Mahkamah Konstitusi. Badan peradilan yang dimaksud mencakup 4 (empat) wilayah hukum, yang secara resmi diakui dan berlaku di Indonesia yaitu Peradilan Umum, Peradilan Agama, Peradilan Militer dan Peradilan Tata Usaha. ${ }^{5}$

Kewenangan di lingkungan peradilan dibedakan menjadi 2 (dua), yaitu kewenangan relatif (relative competentie) dan kewenangan absolut (absolute competentie). Kompetensi Peradilan Agama dirumuskan sebagai kekuasaan negara dalam menerima, memeriksa, mengadili, dan memutus, serta menyelesaikan perkaraperkara tertentu antara orang-orang yang beragama Islam untuk menegakkan hukum dan keadilan. Dalam hal ini arti kekuasaan negara adalah kekuasaan kehakiman.

Kewenangan mutlak atau yang sering disebut dengan kompetensi absolut yaitu kewenangan yang menyangkut kekuasaan mutlak untuk mengadili suatu perkara, artinya perkara tersebut hanya bisa diperiksa dan diadili oleh Pengadilan Agama yang dalam istilah lain disebut Atribut Van Rechsmacht. Sebagai contoh, perkara perceraian bagi orang-orang yang beragama Islam dan perkawinannya dilakukan secara Islam menjadi kewenangan absolut Pengadilan Agama. ${ }^{6}$

Kewenangan relative atau yang sering disebut kompetensi relative yaitu kewenangan mengadili suatu perkara yang menyangkut wilayah/daerah hukum (yurisdiksi). Hal ini dikaitkan dengan tempat tinggal pihak-pihak berperkara. Dalam istilah lain, kewenangan relative ini disebut distribute van rechtsmacht. Sedangkan pengadilan yang berhak mengadili suatu perkara dalam bahasa latin disebut dengan istilah "Actor Sequitur Forum Rei".

\footnotetext{
Pasal 18.

${ }^{5}$ Republik Indonesia, Undang-Undang Nomor 48 Tahun 2009 tentang Kekuasaan Kehakiman, ${ }^{6}$ Ibid., 117.
} 
Bila merujuk pada dua definisi kewenangan di atas, maka jelas sudah bahwa kompetensi yang akan menjadi objek pada penelitian ini adalah kompetensi absolut Pengadilan Agama. Dalam hal ini, peradilan agama bertugas dan berwenang memeriksa, memutus dan menyelesaikan perkara di tingkat pertama antara orangorang yang beragama Islam di bidang (1) perkawinan; (2) waris; (3) wasiat; (4) hibah; (5) wakaf; (6) zakat; (7) infaq; (8) shadaqah; dan (9) ekonomi syariah. ${ }^{7}$

Selanjutnya dalam penjelasan Pasal 49 Undang-Undang Nomor 3 Tahun 2006 tentang Peradilan Agama dinyatakan bahwa yang dimaksud dengan "perkawinan" adalah hal-hal yang diatur dalam atau berdasarkan undang-undang mengenai perkawinan yang berlaku yang dilakukan menurut syari' ah, antara lain: (1) izin beristri lebih dari seorang; (2) izin melangsungkan perkawinan bagi orang yang belum berusia 21 (dua puluh satu) tahun, dalam hal orang tua wali, atau keluarga dalam garis lurus ada perbedaan pendapat; (3) dispensasi kawin; (4) pencegahan perkawinan; (5) penolakan perkawinan oleh pegawai pencatat nikah; (6) pembatalan perkawinan; (7) gugatan kelalaian atas kewajiban suami dan istri; (8) perceraian karena talāq; (9) gugatan perceraian; (10) penyelesaian harta bersama; (11) penguasaan anak-anak; (12) ibu dapat memikul biaya pemeliharaan dan pendidikan anak bilamana bapak yang seharusnya bertanggung jawab tidak mematuhinya; (13) penentuan kewajiban memberi biaya penghidupan oleh suami kepada bekas istri atau penentuan suatu kewajiban bagi bekas istri; (14) putusan tentang sah tidaknya seorang anak; (15) putusan tentang pencabutan kekuasaan orang tua; (16) pencabutan kekuasaan wali; (17) penunjukan orang lain sebagai wali oleh pengadilan dalam hal kekuasaan seorang wali dicabut; (18) penunjukan seorang wali dalam hal seorang anak yang belum cukup umur 18 (delapan belas) tahun yang ditinggal kedua orang tuanya; (19) pembebanan kewajiban ganti kerugian atas harta benda anak yang ada di bawah kekuasaannya; (20) penetapan asalusul seorang anak dan penetapan pengangkatan anak berdasarkan hukum Islam; (21) putusan tentang hal penolakan pemberian keterangan untuk melakukan perkawinan campuran; (22) pernyataan tentang sahnya perkawinan yang terjadi sebelum Undang-

${ }^{7}$ Republik Indonesia, Undang-Undang Nomor 3 Tahun 2006 tentang Perubahan Atas UndangUndang Nomor 7 Tahun 1989 tentang Peradilan Agama, Pasal 49. 


\section{A. Zamakhsyari Baharuddin, Rifqi Qowiyul Iman}

Undang Nomor 1 Tahun 1974 tentang Perkawinan dan dijalankan menurut peraturan yang lain.

Jika merujuk pada literatur tentang histori kompetensi absolut Pengadilan Agama di Indonesia, rasanya tidak berlebihan jika dikatakan bahwa kewenangan Pengadilan Agama menyelesaikan perkara cerai gugat bak anak sulung. Bahkan kala pemerintah Belanda merubah pendiriannya tentang pemberlakuan hukum Islam di Indonesia karena ada usul dari Snouck Hurgronje kepada pemerintah Belanda agar tidak memberlakukan hukum Islam secara käffah di daerah jajahan dengan menerbitkan Stbl. 1937 No. 116 dan 610, gugat cerai (fasakh) dan rujü tetap menjadi kewenangan peradilan agama. ${ }^{8}$

Hal ini logis sebagaimana argumen Yahya Harahap bahwa setiap pribadi yang mengaku dirinya muslim, pasti akan berhadapan dan mengalami peristiwa yang berkenaan dengan hukum sosial kekeluargaan yang diajarkan Islam. Sekalipun kadar kualitas keislamannya tidak sempurna, namun dalam persitiwa yang berkenaan dengan perkawinan, mereka secara sadar berpaling ke arah hukum Islam. Hampir jarang yang berani mengabaikan dan menyingkirkan sekalipun mungkin dalam pelaksaaan dipadu dengan seremonial tata cara yang bernilai adat. ${ }^{9}$

Olehnya itu persoalan pernikahan dan perkawinan yang menjadi kompetensi absolut dari Peradilan Agama, namun tidak menutup kemungkinan penyelesaian jika terjadi pemutusan hubungan pernikahan dilaksanakan secara adat istiadat yang berlaku pada daerah masing-masing.

\section{Cerai Gugat: Definisi dan Aspek Yurudisnya di Indonesia}

Secara umum aturan mengenai perceraian di Indonesia telah digariskan dalam Undang-Undang No. 1 Tahun 1974 tentang Perkawinan sebagaimana telah diubah dengan Undang-Undang No. 16 Tahun 2019 tentang Perubahan atas Undang-undang No. 1 Tahun 1974 tentang Perkawinan (selanjutnya disingkat dengan UUP), Peraturan

\footnotetext{
${ }^{8}$ Mannan Abdul, et.al., Peradilan Agama Ditinjau Dari Berbagai Aspek (Bogor: Diklat Cakim III PPC Terpadu II Mahkamah Agung Republik Indonesia, 2013), 314.

${ }^{9}$ Harahap M. Yahya, Kedudukan Kewenangan dan Acara Peradilan Agama (Undang-Undang No. 7 Tahun 1989), Ed. 3 (Jakarta: Sarana Bakti Semesta, 1997), 17-18.
} 
Pemerintah Nomor 9 Tahun 1975 tentang Pelaksanaan Undang-Undang Nomor 1 Tahun 1974 tentang Perkawinan (selanjutnya disingkat dengan PP No. 9/1975). Pasal 38 Undang-Undang Perkawinan (UUP) menyatakan bahwa perkawinan dapat putus karena kematian, perceraian, dan atas keputusan pengadilan. Selanjutnya pada Pasal 39 ayat (1) dikatakan bahwa perceraian hanya dapat dilakukan di depan sidang pengadilan setelah pengadilan yang bersangkutan berusaha dan tidak berhasil mendamaikan keduanya.

Cerai gugat atau yang dinarasikan dengan frasa gugatan cerai dalam UUP dan PP No. 1/1975 tersebut adalah gugatan yang diajukan oleh suami atau istri atau kuasanya ke pengadilan yang daerah hukumnya meliputi tempat kediaman tergugat (Pasal 40 Undang-Undang Perkawinan jo. Pasal 20 ayat (1) PP No. 9/1975). Sedangkan bagi pasangan suami istri beragama Islam tunduk pada Kompilasi Hukum Islam (selanjutnya disebut KHI) yang berlaku berdasarkan Instruksi Presiden Nomor 1 Tahun 1991.

UUP telah mengklasifikasikan secara tegas bentuk dan tata cara cerai talāq dengan cerai gugat, berbeda sebagaimana yang diatur dalam PP No. 9/1975. Kedua bentuk perceraian diatur dalam paragraf yang berbeda. Cerai talāq diatur dalam Bab. IV Bagian Kedua paragraf 2 (dua), dan cerai gugat diatur dalam paragraf 3 (tiga). Demikian pula istilah cerai gugat yang terdapat dalam KHI tidak sepenuhnya sama dengan istilah yang terdapat dalam UUP maupun PP No. 9/1975.

Moulia mengemukakan perbedaan tersebut sebagaimana berikut: (1) Dalam UUP dan PP No. 9/1975 disebutkan bahwa gugatan cerai dapat diajukan oleh suami atau istri, sebagaimana yang terdapat dalam Pasal 20, sedangkan gugatan cerai menurut KHI hanyalah gugatan yang diajukan oleh istri sebagaimana yang terdapat dalam Pasal 132 ayat 1 KHI; (2) Dalam KHI dikenal dua macam gugatan cerai, yaitu: Pertama, gugatan cerai yang diajukan oleh istri tanpa kewajiban membayar tebusan, macam yang pertama ini sama dengan gugatan cerai yang diatur dalam UUP dan PP 9/19751 Kedua, gugatan cerai dengan kewajiban membayar 'iwaḍ, yaitu istri membayar sejumlah tebusan kepada suami untuk kemudian menceraikannya, gugatan cerai ini disebut khuluk (khul $\vec{u})$. khulu' tersebut tidak terdapat ketentuannya dalam UUP dan 


\section{A. Zamakhsyari Baharuddin, Rifqi Qowiyul Iman}

PP No. 9/1975. ${ }^{10}$ Mencermati dasar dari aturan perceraian ini diketahui bahwa baik itu cerai talāq maupun cerai khuluk memiliki dasar dalam pengajuannya kepada Pengadilan Agama.

Pada Pedoman Pelaksanaan Tugas dan Administrasi Peradilan Agama dinyatakan bahwa cerai gugat adalah perceraian yang diajukan oleh istri yang petitumnya memohon agar Pengadilan Agama/Mahkamah Syar'iyah memutuskan perkawinan penggugat dengan tergugat. Sedangkan taläq khul $u^{7}$ merupakan gugatan istri untuk bercerai dari suaminya dengan tebusan. ${ }^{11}$

Harahap menyatakan bahwa upaya cerai gugat dihubungkan dengan tata tertib beracara benar-benar murni bersifat contentiosa. Ada sengketa yakni sengketa perkawinan yang menyangkut perkara perceraian. Ada pihak-pihak yang sama-sama berdiri sebagai subjek perdata. Istri sebagai pihak penggugat, dan suami sebagai pihak tergugat. Oleh karena sifat gugatan bersifat contentiosa, serta pihak-pihak terdiri dari dua subjek yang saling berhadapan dalam kedudukan hukum yang sama derajat, proses pemeriksaan cerai gugat benar-benar murni bersifat contradictoir, sehingga dari segi hukum acara perdata dalam perkara gugat, telah terpenuhi persyaratan yang memungkinkan penjatuhan putusan yang mengandung amar condemnatoir. ${ }^{12}$

Meski demikian, dalam cerai gugat yang berbentuk khulü, penyelesaian hukumnya akan diakhiri dengan tata cara cerai talāq. Seolah-olah kedua bentuk upaya perceraian bertemu. Prosesnya mula-mula mengikuti tata cara cerai gugat, tapi akhir penyelesaian perkaranya diakhiri dengan tata cara cerai talāq. Pertemuan kedua bentuk upaya perceraian bisa terjadi dalam cerai gugat $k h u l u^{7}$, karena tuntutan hukum Islam yang terkandung dalam khulü itu sendiri. Menurut hukum Islam, khulủ adalah hak istri untuk mengajukan tuntutan perceraian kepada suami dengan cara suami bersedia

\footnotetext{
${ }^{10}$ Nouvan Moulia, "Kedudukan Khuluk Dalam Perspektif Undang-Undang Perkawinan Indonesia dan Fikih Islam (Analisis Putusan Pengadilan Agama Pasir Pengaraian, nomor 273/Pdt.G/2015/PA.Ppg)," Ius Civile: Refleksi Penegakan Hukum dan Keadilan, Vol. 2, No. 1 (2018): $78-88$.

${ }^{11}$ Ibrahim Ahmad Harun, Pedoman Pelaksanaan Tugas dan Administrasi Peradilan Agama, Revisi. (Jakarta: Mahkamah Agung RI Direktorat Jenderal Badan Peradilan Agama, 2013), 132.

${ }^{12}$ Yahya Harahap, Kedudukan Kewenangan dan Acara Peradilan Agama (Undang-Undang No. 7 Tahun 1989)(Jakarta: Sinar Grafika, 1990), 252.
} 
menalak istri dengan suatu imbalan penggantian atau 'iwad. ${ }^{13}$ Pendapat Harahap tersebut kemudian diakomodir dalam KHI yang terbit beberapa tahun kemudian.

Pada Pasal 119 KHI dinyatakan bahwa pengadilan dalam hal menjatuhkan taläq maka talāq tersebut dikategorikan sebagai taläq bäin ṣugrah yakni țalāq yang tidak boleh dirujuk tapi boleh akad nikah baru dengan bekas suaminya meskipun dalam 'iddah. Talāq bāin ṣugrah sebagaimana ketentuan dalam KHI meliputi talāq yang terjadi qabla dukhūl, talāq dengan tebusan atau khulü, dan talāq yang dijatuhkan oleh Pengadilan Agama (Pasal 119 KHI). Kewenangan menjatuhkan talāq oleh peradilan bisa dikatakan proporsional bila dihubungkan dengan pendapat Harahap yang menyatakan bahwa dalam hal cerai gugat, gugatan bersifat contentiosa, serta pihakpihak terdiri dari dua subjek yang saling berhadapan dalam kedudukan hukum yang sama derajat. ${ }^{14}$

Pada dasarnya mengenai masalah mengajukan gugatan perceraian, baik itu cerai talak maupun cerai gugat berpatokan kepada ketentuan pasal 22 Peraturan Pemerintah Nomor 9 Tahun 1975 ayat (1) ${ }^{15}$ dan pasal 66 serta pasal 73 Undang-Undang Nomor 7 Tahun 1989. Dari dua aturan di atas, maka dapat dipahami aturan mana yang mempunyai sifat yang lebih khusus, sehingga dapat menyampingkan aturan yang sifatnya umum. Asas ini sejalandengan teori takhsish dalam ushul fiqh, yaitu merupakan penjelasan mengenaikandungan suatu hukum yang umum menjadi berlaku khusus sesuai dengan lafaz yang dikhususkan tersebut. ${ }^{16}$ Dengan kata lain, bahwa takhsish menjelaskan bahwa yang dimaksud syari' dari hukum yang bersifat umum sejak semula bukan yang bersifat umum tersebut, tetapi hukum yang bersifat khusus. ${ }^{17}$ Jadi apabila suatu hukum itu datang dalam bentuk umum, maka diamalkanlah hukumtersebut menurut keumumannya, kecuali apabila ada dalil yang menunjukkan adanya penjelasan (takhsish). ${ }^{18}$

\footnotetext{
${ }^{13}$ Ibid., 253.

${ }^{14} \mathrm{Ibid}, \mathrm{g} 252$.

${ }^{15}$ Gugatan perceraian diajukan oleh suami atau istri atau kuasanya kepada Pengadilan yang daerah hukumnya meliputi tempat kediaman tergugat.

${ }^{16}$ Rahmat Syafe'i, Ilmu Ushul Fiqih (Bandung: Pustaka Setia, 2007), 233.

${ }^{17}$ Firdaus, Ushul Fiqh: Metode Mengakaji dan Memahami Hukum Islam Secara Komprehensif (Jakarta: Zikrul Hakim, 2004), 205-206.

${ }^{18}$ Amir Syarifuddin, Ushul Fiqh, Jilid 2 (Cet. 4; Jakarta: Kencana, 2008), 87.
} 


\section{A. Zamakhsyari Baharuddin, Rifqi Qowiyul Iman}

Selanjutnya penulis berpendapat, apabila dilihat dari sudut pandang undangundang terutama pada pasal 1 dan pasal 33 Undang-Undang Nomor 1 Tahun 1974 jo. Pasal 3 dan pasal $77 \mathrm{KHI}$, bahwa ababila antara suami isteri tersebut sudah tidak bisa dirukunkan lagi dalam suatu ikan perkawinan. Meski pada dasarnya, yang berbuat salah istri, namun berdasarkan undang-undang ini tujuan perkawinan sudah tidak dapat dicapai dan hak dan kewajiaban suami isteri tidak bisa dipenuhi, maka perceraian dianggap sulusi yang paling baik di antara suami isteri. ${ }^{19}$ Sejalan dengan itu Islam telah memilih jalan perceraian pada saat kehidupan rumah tangga mengalami ketegangan dan kegoncangan yang berat, sudah tidak berguna lagi nasehat-nasehat dan tidak tercapai lagi perdamaian antara suami-istri serta ikatan perkawinan sudah mencerminkan tidak mungkin akan dapat mencapai tujuannya, sebab mengharuskan untuk tetap melestarikan dan mempertahankan perkawinan tersebut sama halnya dengan menghukum salah satu pihak dengan hukuman seumur hidup dan ini adalah kedzaliman yang ditentang oleh jiwa keadilan.

\section{Kompetensi Peradilan Agama dalam Penanganan Cerai Gugat Perspektif Fikih}

Kata cerai dalam terminologi fikih dibahasakan dengan istilah talāq yang secara bahasa berarti melepaskan (al-hill) atau mengurai ikatan (raf'u al-qayd). Dalam definisi para fuqaha, talāq berarti melepaskan ikatan pernikahan saat ini atau pada waktu yang ditentukan kemudian dengan lafadz khusus atau yang menduduki kedudukannya (lafadz tersebut). Nikah dalam hal ini tidak lain adalah nikah yang sah (al-nikāh alșahīh) sehingga dalam hal nikāh fāsid țalāq menjadi tidak sah namun dilakukan dengan mutārakah ataupun fasakh. Asalnya, talāq merupakan hak perogratif suami, namun dalam beberapa hal ia dapat diwakilkan sebagaimana talāq melalui perwakilan (wakālah) dan penyerahan (tafwị̣̂). Namun ada pula talăq yang jatuh tanpa suami mewakilkannya seperti talāq oleh hakim ( $q \bar{a} \bar{a} \overline{1} \overline{1})$ dalam beberapa situasi. ${ }^{20}$

\footnotetext{
${ }^{19}$ Eka Putra, "Kompetensi Pengadilan Agama dalam Penyelesaian Gugatan Perceraian dan Hadhanah menurut Hukum Positif (Studi Kasus terhadap Putusan Pengadilan Agama Sungai Penuh Nomor: 0062/PDT.G/2011/PA.SPN), Al-Qishthu, Vol. 14, No. 2 (2016); 181.

${ }^{20}$ Kementerian Wakaf dan Urusan Agama Kuwait, Al-Mausu'ah al Fiqhiyah al Kuwaityah, Ed. 2, Vol. 29 (Kuwait: Thiba'ah Dzat al Salasil, 1983), 5-6.
} 
Kaitannya dengan perceraian terdapat setidaknya beberapa istilah dalam literature fikih. Istilah tersebut antara lain talāq, khulu', fasakh, dan tafríq. Istilah yang disebut terakhir mungkin tidak sepopuler yang sebelumnya, mengingat ketiga istilah pertama telah dicantumkan dalam aturan perundang-undangan. Bila melalui pendekatan terminologis, talāq, khulu', fasakh, dan tafríq dapat dibedakan sebagai berikut; (1) talāq adalah menghilangkan ikatan pernikahan baik secara langsung ataupun diwaktu yang akan datang dengan lafadz khusus atau sejenisnya, (2) khulu adalah menghilangkan kepemilikan pernikahan dengan lafadz khulv atau sejenisnya dengan adanya 'iwad yang wajib dibayarkan oleh istri ataupun selainnya bagi pihak suami, (3) fasakh adalah putusnya ikatan pernikahan yang dengannya hilanglah akibatakibat suatu akad serta hukum-hukum yang timbul darinya, dan (4) tafríq berarti pemutusan ikatan pernikahan antara suami istri melalui putusan hakim yang didasarkan atas permintaan salah satu pihak karena sebab seperti shiqāq, ḍarar, tidak adanya nafkah, ataupun tanpa adanya permohonan dari salah satu pihak namun dilaksanakan dalam rangka menjaga hak-hak shara' seperti bilamana salah satu pihak keluar dari agama atau murtad. ${ }^{21}$

Wahbah al-Zuhayli menyatakan bahwa al-tafríq berbeda dengan talāq, dimana terjadinya talāq atas pilihan (ihktiyār) dan keinginan suami, sedangkan tafríq dijatuhkan melalui putusan hakim berdasarkan gugatan yang diajukan oleh istri. Hal tersebut agar dimungkinkan bagi istri untuk memutuskan tali pernikahan secara paksa manakala talāq ataupun khul $u^{\top}$ tidak dapat diupayakan. ${ }^{22}$

Al-Tafrìq al-qaựāi dapat berupa talāq yakni bila disebabkan ketiadaan nafkah suami, îtā (sumpah untuk tidak menggauli istri), cacat, shiqāq antara suami istri, hukuman penjara bagi suami (habs) atau juga disebabkan ta'assuf (penyelewengan hak yang dilakukan oleh suami seperti menjatuhkan talāq menjelang kematian). Selain itu ia juga dapat berupa fasakh terhadap akad sejak asal mulanya seperti tafriq terhadap akad yang făsid (rusak), juga tafriq karena salah satu pasangan murtad, ataupun salah

\footnotetext{
${ }^{21}$ Ibid., Vol. 29, 5-6.

${ }^{22}$ Wahbah al-Zuhayli, Mausu'ah al Fiqh al-Islami wa al Qadhaya al-Mu'ashirah, Ed. 3, Vol. 8.
} (Damaskus: Dar al Fikr, 2010), 487. 


\section{A. Zamakhsyari Baharuddin, Rifqi Qowiyul Iman}

satunya masuk Islam. ${ }^{23}$ Dengan demikian, baik laki-laki maupun perempuan memiliki hak yang sama untuk mengajukan perceraian di lembaga peradilan. Dalam ranah fikih, paraktik demikian memiliki alas hukum melalui lembaga yang disebut dengan al-tafriq al-qađ̣ai yang secara etimologis merupakan murakkab wașfỉ yang terbentuk dari dua kata dimana salah satunya merupakan kata sifat (adjectiva) dan lainnya merupakan isim (nomina) yang disifati. Dalam hal ini penulis, mencoba mengartikan kata perkata sebelum nantinya penulis paparkan makna dari al-tafríq al-qađ̣aìi secara definitif.

Al-Tafríq secara etimologi merupakan bentuk mașdar(kata dasar) dari 'farraqa' (past tense) yang berarti memisahkan. Dalam kosakata bahasa Arab kata al-tafriq memiliki beberapa istilah yang hampir serupa yakni al-tajzi 'ah atau al-qismāh yang berarti pembagian, al-tamyïz yang berarti pemisahan, al-tabaddud yang berarti terpisah, dan al-fașl yang berarti pemisahan. ${ }^{24}$ Istilah lain sebagaimana dinarasikan oleh Sayyid Sābiq yakni al-tattiq yang berarti menceraikan dan dalam beberapa literature digunakan istilah al-firqah. Sedangkan al-qaḍ̄a secara etimologi pun berasal dari kosakata bahasa Arab yang merupakan mașdar dari kata qạ̣āyang berarti al-qat ' $u$ atau memutuskan, al-faṣl yakni memisahkan dan dapat juga bermakna al-ḥkm atau hukum. $^{25}$

Secara terminologi al-tafriq al-qađ̣a $\bar{a}$ adalah putusnya hubungan pernikahan melalui putusan hakim atas dasar gugatan seorang istri. ${ }^{26}$ Dalam redaksi yang lain alZarqānì menyebutkan bahwa al-tafrì $q$ adalah putusnya hubungan pernikahan melalui putusan hakim atas dasar permohonan salah satu pihak (suami atau istri). ${ }^{27}$ Sedangkan bila didasarkan pada literatur-literatur kontemporer, al-tafriq al-qaḍai adalah "pemutusan ikatan pernikahan antara suami istri melalui putusan hakim yang didasarkan atas permintaan salah satu pihak karena sebab seperti shiqāq, đ̣arar, tidak adanya nafkah, ataupun tanpa adanya permohonan dari salah satu pihak namun

\footnotetext{
${ }^{23}$ Ibid., Vol. 8, 487.

${ }^{24}$ Sa'di Abu Jayb, Al-Qamus al-Fiqhi Lughatan Wasthilahan, Ed. 2 (Damaskus: Dar al Fikr, 1988), 283.

${ }^{25}$ Muhammad ibn Mukarram al-Mishri ibn Manzur, Lisan al-'Arab, Ed. 3 (Bairut: Mu'assasah al-Tarikh al-'Arabi, Dar Ihya al-Turats al 'Arabi, 1993), 283.

${ }^{26}$ Muhammad Amin ibn 'Abidin, Radd al-Mukhtar 'ala al-Dur al Mukhtar Sharh Tanwir alBasair," Ed. 1, Vol. 4 (Bairut: Dar al Kutub al 'Ilmiyah, 1994), 186.

${ }^{27}$ Muhammad ibn Abd al-Baqi ibn Yusuf al-Zarqani, Sharh al Zarqani 'ala Muwattha' al-Imam Malik, Ed. 1, Vol. 3 (Bairut: Dar al-Kutub al-'Ilmiyah, 1990), 277.
} 
dilaksanakan dalam rangka menjaga hak-hak shara' seperti bilamana salah satu pihak keluar dari agama (murtad)". ${ }^{28}$

Pada literatur yang lebih kontemporer, al-tafríq al-qậai didefinisikan dengan melepaskan ikatan pernikahan dengan putusan hakim, baik pada saat itu (ḥālan) maupun di waktu yang akan datang (ma'ālan) berdasarkan perintah syari'at atau permintaan salah satu pasangan. ${ }^{29}$ al-Najjār menjelaskan bahwa narasi "pada saat itu (hậA)" maksudnya adalah talāq bäin dan fasakh yang berakibat putusnya tali pernikahan saat itu juga, sedangkan "di waktu yang akan datang (ma'āt)" maksudnya adalah talāq raj' $\bar{i}$ yang mana putusnya pernikahan tidak secara langsung pada saat talāq dijatuhkan. ${ }^{30}$

Wahbah al-Zuhayli dan al-Sayyid Sābiq telah mengkategorikan situasi di mana lembaga peradilan berwenang memutus tali pernikahan antara lain: (1) ketika suami tidak menafkahi istri ('adam al-nafaqah), (2) karena adanya aib/cela ('ayb aw 'ilal) (3) karena perselisihan dan mudharat (al-shiqāq aw al-ḍarar) (4) Karena ketiadaan suami tanpa uzur (gaybah al-zawj bilà 'udzr), dan (5) karena suami dihukum dengan hukuman penjara (habs). ${ }^{31}$ Mengutip Baharuddin dan Iman asbab tersebut nyatanya banyak dijadikan sumber hukum yang diadopsi oleh undang-undang terkait alasan-alasan perceraian. $^{32}$

Pasal 19 Peraturan Pemerintah No. 9 Tahun 1975 tentang Pelaksanaan UndangUndang No. 1 Tahun 1974 tentang perkawinan antara lain: (1) salah satu pihak berbuat zina atau menjadi pemabok, pemadat, penjudi, dan lain sebagainya yang sukar disembuhkan; (2) salah satu pihak meninggalkan pihak lain selama 2 (dua) tahun berturut-turut tanpa izin pihak lain dan tanpa alasan yang sah atau karena hal lain diluar kemampuannya; (3) salah satu pihak mendapat hukuman penjara 5 (lima) tahun

\footnotetext{
${ }^{28}$ Kuwait, Al-Mausu'ah al-Fiqhiyah al-Kuwaityah, Vol. 29, 6.
}

${ }^{29}$ Adnan Ali al-Najjar, Al-Tafriq al-Qadha'i baina al-Zaujayni Dirasatan Fiqhiyyatan Muqaranatan Biqanun al-Ahwal al Syahshiyyah al-Falisthini (Palestina: Islamic University of Gaza, 2004), 6.

${ }^{30}$ Ibid., 6.

${ }^{31}$ Zuhayli, Mausu'ah al Fiqh al-Islami wa al-Qadhaya al-Mu'ashirah, Vol. 8, 487.; Sayyid Sabiq, Fiqh al Sunnah, Vol. 2 (Kairo: al-Fath lil 'Ilam al-’Arabi, Dar Mishr li al-Thiba'ah, t.th.), 186.

${ }^{32}$ A. Zamakhsyari Baharuddin dan Rifqi Qowiyul Iman, "At-Tafrî̀ Al-Qadhâi and The Religious Courts' Authority In Deciding A Divorce," Syariah: Jurnal Hukum dan Pemikiran, Vol. 20, No. 1 (2020): 1-12. 


\section{A. Zamakhsyari Baharuddin, Rifqi Qowiyul Iman}

atau hukuman yang lebih berat setelah perkawinan berlangsung; (4) Salah satu pihak melakukan kekejaman atau penganiayaan berat yang membahayakan pihak yang lain; (5) salah satu pihak mendapat cacat badan atau penyakit dengan akibat tidak dapat menjalankan kewajibannya sebagai suami/istri; dan (6) antara suami dan istri terusmenerus terjadi perselisihan dan pertengkaran dan tidak ada harapan akan hidup rukun lagi dalam rumah tangga.

Sebagaimana Pasal 116 KHI menyatakan bahwa perceraian dapat terjadi karena alasan atau alasan-alasan: (1) salah satu pihak berbuat zina atau menjadi pemabuk, pemadat, penjudi dan lain sebagainya yang sukar disembuhkan; (2) salah satu pihak meninggalkan pihak lain selama 2 (dua) tahun berturut-turut tanpa izin pihak lain dan tanpa alasan yang sah atau karena hal lain di luar kemampuannya; (3) salah satu pihak mendapat hukuman penjara 5 (lima) tahun atau hukuman yang lebih berat setelah perkawinan berlangsung; (4) Salah satu pihak melakukan kekejaman atau penganiayaan berat yang membahayakan pihak lain; (5) salah satu pihak mendapat cacat badan atau penyakit dengan akibat tidak dapat menjalankan kewajibannya sebagai suami atau istri; (6) antara suami dan istri terus menerus terjadi perselisihan dan pertengkaran dan tidak ada harapan akan hidup rukun lagi dalam rumah tangga; (7) suami melanggar ta' $\overline{l i q}$ talāq, dan (8) peralihan agama atau murtad yang menyebabkan terjadinya ketidakrukunan dalam rumah tangga.

Ada kondisi lainnya dimana Pengadilan berwenang menjatuhkan talāq, namun masih menjadi khilaf bagi sebagian fuqaha yang memandang sebagiannya sebagai wilayah cerai talāq. Kondisi tersebut antara lain: (1) tafríq dengan khiyār bulūg; (2) tafríq karena perbedaan agama; (3) tafriq karena li’ $\bar{a} n$; (4) tafriq karena rusaknya akad nikah atau hilangnya sifat yang disukai; (5) tafriq karena keharaman yang disebabkan oleh hubungan persusuan (rạ̣a'ah) dan hubungan pernikahan (muṣāharah); (6) tafrīq karena kurangnya mahar; dan (7) tafriq karena suami hilang (faqd). ${ }^{33}$ Berbeda dengan yang pertama, kondisi-kondisi yang terakhir disebut tidak banyak diadopsi dalam

\footnotetext{
${ }^{33}$ Kuwait, Al-Mausu'ah al Fiqhiyah al Kuwaityah, Vol. 29, 77.
} 
perundang-undangan atau qānūn dan hanya dijelaskan dalam literatur fikih klasik saja. $^{34}$

Pertama, cerai gugat karena suami tidak memberi nafkah. Imām Mālik, Imām Shāfi'î, dan Imām Aḥmad menyatakan bahwa diperbolehkan bagi hakim menjatuhkan talāq atas permintaan istri bila suami tidak lagi menafkahinya, dan senyatanya suami tidak sama sekali memiliki harta untuk menunaikan kewajibannya tersebut. ${ }^{35}$

Pendapat ini berlandaskan atas firman Allah swt. dalam QS al-Baqarah/2 ayat 229 yang menyatakan: "maka tahanlah (peliharalah) ia dengan cara yang baik atau ceraikanlah ia dengan cara yang baik pula." Selankutnya dalam QS al-Baqarah/2 ayat 231, Allah swt. berfirman "dan janganlah kamu menahannya untuk suatu kemudharatan sehingga engkau menganiayanya." Terkait ayat tersebut para faqih berpendapat bahwa tiada kemudharatan yang lebih berbahaya daripada tidak diberikannya nafkah bagi seorang istri. Bahwa diantara asas yang prinsipil dalam hukum Islam adalah asas lā ḍarar wa lā dirār atau larangan membahayakan diri ataupun orang lain. ${ }^{36}$

Argumentasi lainnya berdasarkan suatu riwayat dari Abū Zinād yang menyatakan: "Aku bertanya kepada Sa“ỉd Ibn al-Musayyib tentang suami yang tidak punya apa-apa untuk menafkahi istrinya, apakah keduanya dapat diceraikan? Berkata Sa'id Ibn al-Musayyib: "Ya", Lantas aku bertanya lagi: Apakah itu sunnah? Lalu ia menjawab: "Ya sunnah" (yakni sunnah Rasulullah saw.)". Dalam riwayat lainnya dikatakan bahwa 'Umar ibn al-Khațtab menyurati para pemimpin perangnya tentang para suami yang telah meninggalkan istrinya. Dalam suratnya, ia memerintahkan agar mereka menafkahi istrinya atau menceraikannya, dan bila perceraian yang dipilih hendaknya mereka membayar nafkah lampau yang dilalaikannya. ${ }^{37}$

Para ulama berbeda pendapat tentang jenis taläq yang dijatuhkan hakim karena ketiadaan nafkah suami. Kalangan Shāfi'iyah dan Hanābilah berpendapat bahwa tafríq oleh hakim karena ketiadaan nafkah merupakan fasakh. Sedangakan kalangan madzhab

\footnotetext{
${ }^{34}$ Baharuddin dan Iman, At-Tafrîq Al-Qadhầi And The Religious Courts' Authority In Deciding A Divorce, 1-12.

${ }^{35}$ Sabiq, Fiqh al Sunnah, Vol. 2, 186.

${ }^{36}$ Zuhayli, Mausu'ah al Fiqh al-Islami wa al Qadhaya al Mu'ashirah,Vol.8, 488.

${ }^{37}$ Ibid., Vol. 8, 488.
} 


\section{A. Zamakhsyari Baharuddin, Rifqi Qowiyul Iman}

Mālikī menyatakan yang demikian merupakan talāq raj ${ }_{i}$. Dalam hal ini para faqih yang menyatakan tafriq karena ketiadaan nafkah wajib dilaksanakan melalui putusan hakim. Hal tersebut dikarenakan pemisahan yang dilakukan didasarkan atas sebuah ijtihad dan hal tersebut tidak dapat dilakukan kecuali melalui put usan hakim sebagai wujud penyelesaian sengketa. ${ }^{38}$

Kedua, cerai gugat karena adanya aib/cela ('ilal). Cacat badan atau penyakit yang bersifat fisik ataupun mental merupakan salah satu hal yang menghambat keharmonisan rumah tangga. Hal demikian dikarenakan dalam berinteraksi, suami dan istri akan merasakan hambatan hingga menyebabkan salah satu pihak baik suami ataupun istri tidak mampu melaksanakan kewajibannya. Perkara hak dan kewajiban ini sungguh banyak menimbulkan masalah ditengah-tengah rumah tangga, antara lain disebabkan suami tidak mampu memberi nafkah lahir kepada istrinya, seperti kebutuhan sehari-hari, pakaian dan sebagainya. Istri yang tidak tabah menghadapinya serta tidak mau memikirkan kekurangan ekonomi akhirnya menimbulkan pertengkaran. Ataupun suami mempunyai penyakit tidak sanggup bergaul dengan istrinya secara normal atau impoten. Dalam hal ini istri yang tidak senang dengan keadaan suaminnya itu atau istri yang tidak mampu mengendalikan daya seksualnya timbulah krisis, karena menyalurkan begitu saja tanpa proses perkawinan terlarang keras dalam ajaran agama Islam. $^{39}$

Berdasarkan hal tersebut, jumhur ulama berpendapat bahwa kecacatan pada salah satu pihak dapat dijadikan alasan untuk menuntut perceraian. Bahkan mayoritas ulama selain madzhab Hanafí menyatakan bahwa masing-masing suami-istri berhak untuk mengugat cerai dalam bentuk fasakh bila pasangannya mengidap salah satu penyakit tersebut. Argumentasinya adalah, baik laki-laki maupun perempuan samasama berperasaan tidak sabar bergaul dengan pasangannnya yang mengidap salah satu penyakit tersebut.

Bagi pihak suami dibolehkan menuntut fasakh bukan dengan talāq, karena dengan menjatuhkan talāq, suami harus memikul resikonya seperti harus membayar

\footnotetext{
${ }^{38}$ Kuwait, Al-Mausu'ah al-Fiqhiyah al-Kuwaityah, Vol. 29, 61.

${ }^{39}$ Firdaweri, Hukum Islam Tentang Fasakh Nikah Karena Ketidakmampuan Suami Memenuhi Kewajibannya, Ed. 3 (Jakarta: CV. Pedoman Ilmu Jaya, 1988), 2.
} 
mahar jika țalāq dijatuhkan setelah melakukan senggama ( ba'da al-dukhūi), ataupun membayar separuhnya jika talāq dilakukan sebelumnya (qabla al-dukhū $)$. Sedangkan perceraian disebabkan adanya aib, atau cacat, pihak suami tidak diharuskan membayar separuh mahar jika fasakh terjadi sebelum bersenggama (qabla al-dukhūi), dan jika fasakh terjadi setelah senggama ( $b a^{\prime} d a$ al-dukhūt), meskipun ulama sepakat bahwa suami harus membayar sejumlah mahar yang telah disepakati, namun menurut pendapat kalangan Mālikiyah, Shāfi'iyah dan Hanābilah, suami dalam hal ini dibenarkan untuk menuntut ganti rugi uang mahar itu kepada wali wanita seperti ayah atau saudaranya karena selama ini mereka telah menyembunyikan kelemahan masingmasing. Istri yang diceraikan karena ada penyakit ini tidak berhak nafkah 'iddah dan tidak pula tempat tinggal. ${ }^{40}$

Para fuqaha madzhab Hanafí dan Mālikì menyatakan bahwa firqah sebab adanya cacat atau aib merupakan talāq bāin dan bahwasanya perceraian karena aib atau cela harus dilakukan melalui putusan hakim. Sedangkan Madzhab Shāfi ‘َi dan Hanbali menyatakan bahwa tafríq yang demikian merupakan fasakh dan bukan talāq. ${ }^{41}$

Ketiga, cerai gugat karena shiqāq atau đ̣arār. Dinyatakan oleh Imām Mālik bahwa diperbolehkan bahkan dianjurkan bagi istri untuk mengajukan gugatan cerai kepada hakim bila terdapat hal-hal yang membahayakan dalam pernikahannya sehingga keharmonisan rumah tangganya tidak dapat lagi dipertahankan. Hal-hal demikian bisa saja disebabkan adanya kekerasan dalam rumah tangga (KDRT), sifat penghinaan/caci maki dari pihak suami, serta tindakan-tindakan aniaya lainnya yang bersifat tidak layak, termasuk paksaan dari pihak suami agar istri melakukan perbuatan munkar. ${ }^{42}$

Adapun yang dimaksud dengan ḍarär sebagaimana definisi Wahbah al-Zuhayli adalah:

\footnotetext{
${ }^{40}$ M. Zein Satria Effendi, Problematika Hukum Keluarga Islam Kontemporer, Analisis Yurisprudensi Dengan Pendekatan Ushuliyah, Ed. 2 (Jakarta: Kencana, 2004), 132.

${ }^{41}$ Kuwait, Al-Mausu'ah al-Fiqhiyah al-Kuwaityah, Vol. 29, 76.

${ }^{42}$ Sabiq, Fiqh al Sunnah, Vol. 2, 187.
} 


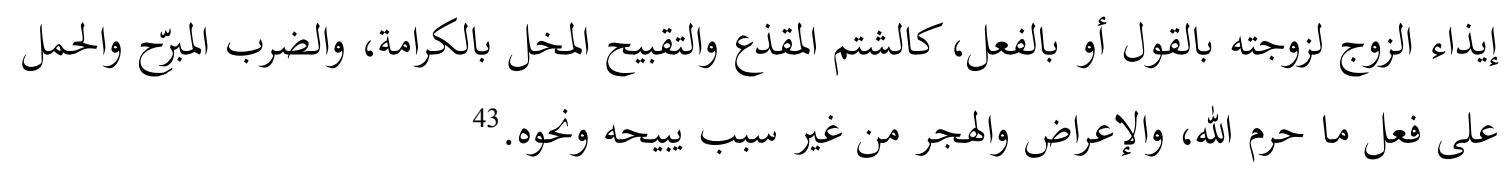

Artinya:

Perbuatan suami menyakiti istrinya denga perkataan ataupun perbuatan, seperti cacimaki, pelecehan yang merendahkan martabat, pemukulan yang parah, ajakan untuk melakukan apa yang dilarang oleh Allah swt., dan mengabaikan serta berpaling tanpa alasan yang sah dan lain sebagainya.

Para fuqaha Mālikiyah dan Imām Aḥmad menyatakan kebolehan hakim untuk memutus perceraian karena adanya kemudharatan ${ }^{44}$ Hal tersebut berdasarkan sabda Nabi Muhammad saw.:

$$
\text { لاَ ضَرَرَ وَلاََ ضِرَارَ }
$$

Artinya:

Tidak boleh melakukan kemudhorotan dan tidak boleh juga memudhorotkan orang lain."

Berdasarkan hal tersebut bilamana seorang istri mengajukan gugatan cerai kepada Pengadilan, dan ia mampu membuktikan adanya bahaya (ḍarar) dalam hubungan pernikahannya, maka hakim berwenang menjatuhkan talāq bagi istri tersebut. Dalam hal ini tafrịq yang dilakukan karena shiqāq adalah talāq bāin dan merupakan talāq satu sebagaimana dinyatakan kalangan Mālikiyah. ${ }^{45}$

Keempat, cerai gugat karena ketiadaan suami (gaybah al-zawj). Diperbolehkannya menjatuhkan talāq sebab ketiadaan suami merupakan pendapat madzhab Mālikiyah dan Hanābilah. Seorang istri dapat meminta hakim untuk menjatuhkan talāq disebabkan ketiadaan suaminya meskipun ia memiliki harta untuk dibelanjakan. Namun ada beberapa syarat yang harus terpenuhi yakni: (1) ketiadaan suami bukan dikarenakan adanya uzur yang dapat diterima, (2) istri merasa terancam bahaya ( ̣̂răr) dengan ketiadaan suaminya, (3) ketiadaan suaminya karena ia berada di luar daerah tempat istri berada, dan (4) hendaknya telah lampau waktu 1 (satu) tahun semenjak istri merasakan ancaman bahaya (ḍarar). Bilamana ketiadaan suami

\footnotetext{
${ }^{43}$ Zuhayli, Mausu'ah al-Fiqh al-Islami wa al -adhaya al-Mu'ashirah, Vol. 8, 502.

${ }^{44}$ Ibid., Vol 8, 503.; Sabiq, Fiqh al-Sunnah, Vol. 2, 188.

${ }^{45}$ Kuwait, Al-Mausu'ah al Fiqhiyah al-Kuwaityah, Vol. 29, 56.
} 
disebabkan karena adanya uzur seperti menuntut ilmu, urusan perdagangan, ataupun tugas di luar negeri dan sebagainya, maka tidak dibenarkan tafri ${ }^{46}{ }^{46}$

Alasan yang membenarkan pelaksanaan tafriq dalam hal ini, bahwa istri dengan ketiadaan suami merasa terancam dengan bahaya yang cukup mengkhawatirkan (darar bālig), dan karenanya bahaya tersebut sedapat mungkin harus dihilangkan sebagaimana sabda Nabi Muhammad saw. sebelumnya.

Para faqih selanjutnya berbeda pendapat mengenai berapa lama jangka waktu ketiadaan suami sehingga hakim dapat memutus perceraian (tafríq). Para fuqaha Mālikiyah dalam pendapat yang mu'tamad menyatakan batas maksimal ketiadaan suami baik dikarenakan uzur syar'i ataupun tidak adalah 1 (satu) tahun atau lebih, dan dalam salah satu pendapat madzhab dinyatakan batas maksimalnya adalah 3 (tiga) tahun. Selanjutnya hakim dapat langsung memutus perceraian bila istri mengajukan gugatan cerai sedangkan keberadaan suami tidak diketahui (majhū $)$. Namun bila keberadaan suami diketahui, hendaknya hakim mengirimkan surat yang berisi peringatan untuk kembali, atau mengirimkan nafkah kepada istri, atau bahkan menceraikannya dalam jangka waktu tertentu yang ditetapkan. Dan bilamana surat tersebut diabaikan oleh suami, maka hakim dapat memutuskan perceraian atas kedua pasangan tersebut. Dalam hal ini talāq yang dijatuhkan oleh hakim merupakan talāq bāin dan bahwasanya setiap tafríq yang dilaksanakan oleh hakim menjadi talāq bāin kecuali tafríq disebabkan $\bar{i} l \widehat{a}$ dan tidak adanya nafkah suami. ${ }^{47}$

Para ulama yang menyatakan adanya tafri $\bar{q}$ karena ketiadaan suami sepakat bahwa putusnya pernikahan harus dilaksanakan melalui putusan hakim. Hal tersebut dikarenakan tindakan tafríq (memisahkan) tersebut merupakan sebuah produk ijtihad dan ia tidak dapat dieksekusi tanpa adanya putusan hakim. Adapun tentang jenis talāq yang dijatuhkan, para ulama berbeda pendapat. Kalangan Hanabilah menyatakan bahwa firqah karena ketiadaan suami merupakan fasakh. Berbeda dengan madzhab Mālikì dalam pendapat yang rājih, menyatakan bahwa talāq yang dijatuhkan hakim merupakan talāq bāin. ${ }^{48}$

\footnotetext{
${ }^{46}$ Zuhayli, Mausu'ah al-Fiqh al-Islami wa al-Qadhaya al Mu'ashirah, Vol. 2, 189.

${ }^{47}$ Ibid., Vol. 8,509.

${ }^{48}$ Kuwait, Al-Mausu'ah al-Fiqhiyah al-Kuwaityah, Vol. 29, 64.
} 


\section{A. Zamakhsyari Baharuddin, Rifqi Qowiyul Iman}

Kelima, cerai gugat karena ditahannya suami (habs). Diperbolehkan bagi hakim memutus perceraian bila suami menjalankan hukuman tahanan (habs) atas dirinya. Hal demikian meski bukan merupakan pendapat mayoritas fuqaha, namun ia merupakan ijtihad dari pada para faqih madzhab Māliki. ${ }^{49}$

Para fuqaha Mālikì dalam hal ini menyatakan bilamana istri merasa terancam dengan ditahannya suami, lantas ia mengadukannya kepada hakim maka hakim diperbolehkan menjatuhkan untuk talāq suami atas istri tersebut. Dalam hal ini para fuqaha menetapkan waktu penahanan minimal (1) satu tahun. ${ }^{50}$ Terkait jenis firqah (putusnya pernikahan) nyaris serupa dengan tafriq karena ketiadaan suami. Dalam hal ini talāq yang dijatuhkan oleh hakim merupakan taläq bäin dan bahwasanya setiap tafríq yang dilaksanakan oleh hakim menjadi talāq bāin kecuali tafríq disebabkan ỉlā̉ dan tidak adanya nafkah suami. ${ }^{51}$

\section{E. Kesimpulan}

Di antara salah satu kewenangan mutlak peradilan agama adalah mengadili perkara perkawinan bagi mereka yang beragama Islam. Hal tersebut diatur dalam Pasal 49 UU No. 7 Tahun 1989 yang telah diubah dengan UU No. 3 Tahun 2006 dan telah diubah dengan UU No. 50 Tahun 2009 tentang Peradilan Agama yang menyatakan bahwa lembaga ini berwenang menangani perkara-perkara seputar pernikahan, perceraian, zakat, hibah, infaq, shadaqah, wakaf, dan ekonomi syari'ah, dan di antara perkara dalam bidang perkawinan yang diatur dalam undang-undang tersebut yakni gugatan perceraian. Berdasarkan Pasal 39 UU No. 1 Tahun 1974 tentang Perkawinan menyatakan bahwa perceraian hanya dapat dilakukan di depan sidang pengadilan setelah pengadilan yang bersangkutan berusaha dan tidak berhasil mendamaikan kedua belah pihak.

Al-tafrìq al-qạ̣āi merupakan sebuah kewenangan yang diberikan oleh shära' kepada hakim sekaligus solusi hukum dalam menyelesaikan perasalahan rumah tangga. Bila ditelisik, teryata sebab-sebab adanya kewenangan tersebut seperti suami tidak

\footnotetext{
${ }^{49}$ Sabiq, Fiqh al-Sunnah,Vol. 2, 190.

${ }^{50}$ Kuwait, Al-Mausu'ah al-Fiqhiyah al Kuwaityah, Vol. 29, 29.

${ }^{51}$ Zuhayli, Mausu'ah al-Fiqh al-Islami wa al-Qadhaya al-Mu'ashirah, Vol. 8, 509.
} 
menafkahi istri ('adam al-nafaqah), adanya aib/cela ( 'ayb aw 'ilal), karena perselisihan dan mudharat (al-shiqāq aw al-đ̣arar), ketiadaan suami tanpa uzur (gaybah al-zawj bilā 'udzr), dan suami dihukum dengan hukuman penjara (habs), ataupun sebab-sebab lain yang ditentukan oleh syariat, telah mengindikasikan bahwa kewenangan tersebut merupakan wujud penjagaan (himāyah) terhadap hak-hak perempuan serta hak-hak Allah swt.

Peradilan Agama tidak hanya berkedudukan sebagai lembaga Negara, namun ia juga merupakan lembaga keagamaan sebagaimana tercatat pada literatur-literatur dalam khazanah keislaman. Karenanya, Hakim dalam peradilan agama, selain sebagai pejabat yang melaksanakan fungsi kekuasaan kehakiman, ia juga diasumsikan sebagai ahli agama dengan kewenangan yang diakui oleh shāra'. Karenanya, setiap kewenangan yang dimilikinya selain memiliki pondasi yang dikuatkan oleh hukum negara juga dikokohkan dengan dasar hukum agama.

Seorang hakim yang dengan kewenangannya menjatuhkan talāq, sesungguhnya sedang menjalankan peran amar makruf nahi mungkar. Berdasarkan hal-hal tersebut maka setiap putusan hakim wajib dilaksanakan karena sifat ilzām (mengikat) yang ada padanya. Sifat mengikat tersebut nyatanya diakui oleh syariat, dan dikokohkan dengan kewenangan yang diberikan oleh Negara. Oleh karenanya, siapa saja yang enggan melaksanakan putusan yang dijatuhkan oleh hakim kepadanya sungguh ia telah berdosa secara agama, dan bersalah secara hukum.

\section{Daftar Pustaka}

Abu Jayb, Sa'di. Al-Qamus al-Fiqhi Lughatan Wasthilahan, Ed. 2. Damaskus: Dar al Fikr, 1988.

Baharuddin, A. Zamakhsyari, dan Rifqi Qowiyul Iman, "At-Tafrî̀ Al-Qadha"i and The Religious Courts' Authority In Deciding A Divorce," Syariah: Jurnal Hukum dan Pemikiran, Vol. 20, No. 1, 2020.

Darwis, Rizal. "Hak Nafkah Batin Istri dalam Perkawinan: Telaah Fikih dan Hukum Nasional Perspektif Jender," Disertasi. Makassar: UIN Alauddin Makassar, 2016.

Effendi, M. Zein Satria. Problematika Hukum Keluarga Islam Kontemporer, Analisis Yurisprudensi Dengan Pendekatan Ushuliyah, Ed. 2. Jakarta: Kencana, 2004. 
A. Zamakhsyari Baharuddin, Rifqi Qowiyul Iman

Firdaus. Ushul Fiqh: Metode Mengakaji dan Memahami Hukum Islam Secara Komprehensif(Jakarta: Zikrul Hakim, 2004.

Firdaweri. Hukum Islam Tentang Fasakh Nikah Karena Ketidakmampuan Suami Memenuhi Kewajibannya, Ed. 3. Jakarta: CV. Pedoman Ilmu Jaya, 1988.

Harahap, Yahya. Kedudukan Kewenangan dan Acara Peradilan Agama (UndangUndang No. 7 Tahun 1989). Jakarta: Sinar Grafika, 1990.

Harun, Ibrahim Ahmad. Pedoman Pelaksanaan Tugas dan Administrasi Peradilan Agama, Edisi Revisi. Jakarta: Mahkamah Agung RI Direktorat Jenderal Badan Peradilan Agama, 2013.

Ibn 'Abidin, Muhammad Amin. Radd al-Mukhtar 'ala al-Dur al Mukhtar Sharh Tanwir al-Basair," Ed. 1, Vol. 4. Bairut: Dar al Kutub al 'Ilmiyah, 1994.

Ibn Manzur, Muhammad ibn Mukarram al-Mishri. Lisan al 'Arab, Ed. 3. Bairut: Mu'assasah al-Tarikh al-'Arabi, Dar Ihya al-Turats al 'Arabi, 1993.

Kementerian Agama RI. Ummul Mukminin: Al-Qur'an dan Terjemahan untuk Wanita. Ciputat: Penerbit Wali, 2010.

Kementerian Wakaf dan Urusan Agama Kuwait. Al-Mausu'ah al Fiqhiyah al Kuwaityah, Ed. 2, Vol. 29. Kuwait: Thiba'ah Dzat al Salasil, 1983.

Mannan, Abdul, et.al., Peradilan Agama Ditinjau Dari Berbagai Aspek. Bogor: Diklat Cakim III PPC Terpadu II Mahkamah Agung Republik Indonesia, 2013.

Moulia, Nouvan. "Kedudukan Khuluk Dalam Perspektif Undang-Undang Perkawinan Indonesia dan Fikih Islam (Analisis Putusan Pengadilan Agama Pasir Pengaraian, nomor 273/Pdt.G/2015/PA.Ppg)," Ius Civile: Refleksi Penegakan Hukum dan Keadilan, Vol. 2, No. 1, 2018.

Al-Najjar, Adnan Ali. Al-Tafriq al-Qadha'i baina al-Zaujayni Dirasatan Fiqhiyyatan Muqaranatan Biqanun al-Ahwal al Syahshiyyah al-Falisthini. Palestina: Islamic University of Gaza, 2004.

Pongoliu, Hamid. "Family of Sakinah, Mawaddah, Warahmah in the Concept of Islamic Marriage," Al-Mizan, Vol. 13, No. 1, 2017.

Putra, Eka. "Kompetensi Pengadilan Agama dalam Penyelesaian Gugatan Perceraian dan Hadhanah menurut Hukum Positif (Studi Kasus terhadap Putusan Pengadilan Agama Sungai Penuh Nomor: 0062/PDT.G/2011/PA.SPN), AlQishthu, Vol. 14, No. 2, 2016.

Republik Indonesia, Undang-Undang Nomor 3 Tahun 2006 tentang Perubahan Atas Undang-Undang Nomor 7 Tahun 1989 tentang Peradilan Agama. , Undang-Undang Nomor 48 Tahun 2009 tentang Kekuasaan Kehakiman. 
Roihan, A. Rasyid. Hukum Acara Peradilan Agama, Ed. 2. Jakarta: Raja Grafindo Persada, 2006.

Sabiq, Sayyid. Fiqh al Sunnah, Vol. 2. Kairo: al-Fath lil 'Ilam al-'Arabi, Dar Mishr li al-Thiba'ah, t.th.

Syafe'i, Rahmat. Ilmu Ushul Fiqih. Bandung: Pustaka Setia, 2007.

Syarifuddin, Amir. Ushul Fiqh, Jilid 2. Cet. 4; Jakarta: Kencana, 2008.

Yahya, Harahap M. Kedudukan Kewenangan dan Acara Peradilan Agama (UndangUndang No. 7 Tahun 1989), Ed. 3. Jakarta: Sarana Bakti Semesta, 1997.

Al-Zarqani, Muhammad ibn Abd al-Baqi ibn Yusuf. Sharh al Zarqani 'ala Muwattha' al-Imam Malik, Ed. 1, Vol. 3. Bairut: Dar al-Kutub al-'Ilmiyah, 1990.

Al-Zuhayli, Wahbah. Mausu'ah al Fiqh al-Islami wa al Qadhaya al-Mu'ashirah, Ed. 3, Vol. 8. Damaskus: Dar al Fikr, 2010. 